\title{
Impact Assessment of Competition Policies and Regulation: 10 Years' Experience from the Office of the Chief Economist in the Netherlands
}

\author{
Rob J. M. Alessie $^{1}\left(\mathbb{D} \cdot\right.$ Peter T. Dijkstra $^{2} \cdot$ Ron Kemp $^{2,3}$. \\ Annemieke Tuinstra ${ }^{2}$. Jarig van Sinderen ${ }^{2,3}$
}

Published online: 27 January 2018

(C) Springer Science+Business Media, LLC, part of Springer Nature 2018

\section{Introduction}

On April 1 2006, the Office of the Chief Economist was established at the Netherlands Competition Authority (NMa). To celebrate the tenth anniversary in 2016, the Netherlands Authority for Consumers and Markets (ACM, the NMa's successor) organized a conference on the "Impact assessment of Interventions of Competition and Consumer Authorities". The conference was attended by scientists, policymakers, practitioners and Chief Economists of different competition authorities and the European Commission.

From the very beginning, the NMa's Chief Economist and his team took the initiative to calculate the possible impact of interventions by the Dutch competition and regulatory authority on the economy. In 2008, a Special Issue of De Economist on the possible measurement of the impact of competition authorities was published. ${ }^{1}$ In this 2008 Special Issue the papers concentrated on the pros and cons of quantifying interventions by competition watchdogs. Some authors were rather sceptical about the calculation methods, while others stressed the political necessity of exposing the impact. In the introduction to that Special Issue (Don et al. 2008), it was stressed that some authorities are required by law to provide some form of impact assess-

\footnotetext{
1 See De Economist 156, number 4, published in 2008.

$凶 \quad$ Peter T. Dijkstra

peter.dijkstra@acm.nl

Rob J. M. Alessie

r.j.m.alessie@rug.nl

1 University of Groningen (RUG), Groningen, The Netherlands

2 Netherlands Authority for Consumers and Markets (ACM), The Hague, The Netherlands

3 Erasmus University Rotterdam, Rotterdam, The Netherlands
} 
ment: "Accountability is particularly requested by politics. For instance in the US, the Government Performance and Result Act of 1993 is one of the reasons why the US Department of Justice (US DoJ) and the Federal Trade Commission (FTC) have been calculating the impact of their enforcement activities ever since 1999... Also in the UK, measurement of the impact of enforcement activities is important as consumer savings is one of the targets to be met by the Office of Fair Trading (OFT). Under the 2007 Comprehensive Spending Review settlement, the OFT agreed to the target that the direct financial benefits to consumers are at least five times that of OFT's cost to taxpayers". In the Netherlands, ACM voluntarily publish the impact of its interventions in its annual; report for the first time in 2004. Since that time, several authorities have continued developing the calculation method of the economic impact of their work $^{2}$ and publish about it annually.

Another conclusion of the Special Issue of De Economist in 2008, was that more evaluation studies should be conducted. Such ex-post evaluations are important for two main reasons: they constitute an additional method of justifying the oversight of markets, and they teach the authority which interventions are (most) effective. In the last decade, there has been a growing interest in impact analysis by authorities (as pointed out, for example, by the OECD 2014, 2016). A comparison of methodologies for ex-post evaluations in competition policy has been provided by Davies and Ormosi (2012), and an overview of such ex-post studies in competition policy has been presented in Ilzkovitz and Dierx (2015). An overview of studies on the impact of US merger control has been presented in Kwoka (2014). The European Commission is also actively engaging in impact assessment, as shown by two recent studies considering the impact of competition policy on energy markets (European Commission 2016) and on telecom markets (European Commission 2017).

Ex-post analyses have become more important especially in relation to merger control. Recently, LEAR (2015) performed a study on the effect of several supermarket mergers in the Netherlands on price, quality and variety of product offerings. In the hospital sector, Kemp et al. (2012) investigated the effect of mergers on the price of hip surgery in the Netherlands and found that prices increased at most merged hospitals, and Broers and Kemp (2017) showed that the quality of care did not improve after the merger. In a randomized field experiment, Huizingh and Mulder (2015) investigated the effectiveness of different ways of providing guidance to e-commerce firms about the legal rules on information disclosure, and showed that letters by post mail slightly increased compliance.

Regularly, knowledge and experiences are shared with other regulators and scholars, both domestic and abroad, in order to gain insight into the methods and results of others. This Special Issue gives an overview of such exchange of applied research results on the impact of competition policy. It gives an impression of the state of the art of impact assessment.

$\overline{2}$ The current calculation method of this impact calculation is outlined in Kemp et al. (2014). 


\section{Impact Analysis}

In the first paper of this special issue, John Davies gives an overview of different ways of assessing competition agency performances. These include: activity measurement (e.g. counting the number of completed cases); ex-post evaluations of specific concluded cases; stock market event studies; surveys in which stakeholders provide feedback on the agency performance; wins and losses of agencies in court; and last but not least, outcome measurement (i.e. the assessment of the total benefits of the actions taken by the competition agency). His paper deals especially with the last topic, perhaps because John Davies was responsible for the adoption of the OECD (non-binding) guidelines on outcome measurement when he was Head of the Competition Division at the OECD. He makes it clear that measurement of the impact of interventions on the economy is important. From his UK experience, he recollects that the 1998 and 2002 reforms in UK competition law were inspired by the urge to improve the performance of the British economy. Nevertheless, the limitations of measurement should be kept in mind, for example, what is the counterfactual of the intervention? Another problem is that the dynamic impact in the long term is difficult to measure: what to do with cases which turned out to be mistakes? Simple guidelines in order to take these mistakes into account do not give much extra information in his opinion. Taking deterrence into account creates a problem: more deterrence increases the effectiveness of an authority in the short term, but leads to less outcome in the long term. Still, Davies thinks that calculations of outcome are superior to a measurement consisting of simply counting cases.

Jan Sviták and Jarig van Sinderen also consider the outcome measurement, but study the broader macroeconomic effects of interventions by the ACM. Where the aim of competition policy is to increase general welfare through increased market efficiency, the focus of competition authorities is often directed at the short term impact for consumers. The authors argue that simulating the effect of decreasing market power in a macroeconomic (semi-)general equilibrium model provides useful insights on the impact of competition interventions on macroeconomic variables, such as GDP, employment and productivity. Insights into these effects are important for the political debate on the importance of competition. The authors revise the approach of Van Sinderen and Kemp (2008) by modelling more explicitly the relation between competition and innovation, and introducing the influence on dynamic efficiency as well. The simulation shows that the re-distribution of surplus from the producers to consumers as a result of the enforcement of the competition law over the period 2002-2014 had a positive effect on productivity, GDP, wages, prices, consumption and a small positive effect on employment. Firms' profits decreased as well as the level of investments, but the investments in R\&D increased. This means that overall investments of firms are lower, but more efficient.

Calculation of outcome is one way to get an impression of performance after interventions by competition authorities. Another way is to conduct an ex-post evaluation of specific concluded cases, which compare market developments with a counterfactual, to examine how well intervention or decision of the agency performed. The other studies in this Special Issue consider ex-post evaluations. 
Laura Abrardi, Carlo Cambini and Laura Rondi assess the impact of various regulatory environments and instruments on the investment rate of energy firms. One part of the paper, surveys earlier findings and provides an overview of various regulatory environments during the past decades. The other part of the paper presents new empirical work on about 18 firms in four countries that are active in the electricity and/or gas sector in the period from 1997 to 2013. This empirical part updates earlier work with more recent observations, in order to verify whether earlier results still hold for today. The main result is, in contrast to earlier findings, that investments seem to be driven more by the level of weighted average cost of capital (WACC), than by the level of the X-factor, the efficiency discount used in energy regulation. ${ }^{3}$ Furthermore, Abrardi et al. confirm the previous finding that regulated firms invest more under incentive regulation than under rate-of-return regulation.

Luca Aguzzoni, Benno Buehler, Luca Di Martile, Ron Kemp and Anton Schwarz write about their ex-post evaluation of two specific merger decisions in the Austrian and Dutch telecommunications industry taken by DG Competition. Aguzzoni et al. estimate the price effects using a difference-in-difference (DiD) model, an econometric method commonly used in ex-post merger evaluation literature. The authors find that the merger from 5 to 4 providers, which was cleared with remedies in Austria, seemed to lead to a decrease in prices and certainly did not increase prices. This may be based on strengthened competition due to the imposed merger remedies. In the Netherlands, the merger was from 4 to 3 providers, which was cleared without remedies. There, prices also decreased after the merger, but in comparison to a control group of countries, the relative prices increased in the Netherlands, especially for those whose mobile-phone usage is heavy.

Arno Rasek and Florian Smuda also use a DiD method in their study. They find substantial consumer welfare gains as a result of antitrust measures in the German packaging waste compliance scheme market. Until 2003, DSD held the monopoly rights to organize the nation-wide collection and recycling of packaging waste. Established by the German Packaging Ordinance in 1991, DSD was to operate on a non-profit basis, the idea being that this would prevent DSD from charging excessive prices. However, important producers, retailers and waste management companies quickly became shareholders or partners of DSD. As a result, incentives to compete for collection and recycling contracts were weak at best, which in turn resulted in substantial inefficiencies. Since 2000, a series of antitrust measures by both the Bundeskartellamt (the German Federal Cartel Office) and the European Commission, and a number of pro-competitive amendments to the Packaging Ordinance, have paved the way for market entry and lower price levels. Rasek and Smuda compare the development of prices in the packaging waste compliance scheme market ("treatment market") with the price development in German markets for residential non-packaging waste ("control group"). They find consumer benefits in the range of 8-13 billion euros.

Finally, Peter Dijkstra and Jonathan Frisch analyse the effectiveness of the ACM's leniency programme. This study thus does not consider a specific case, but evaluates a policy change. The ACM introduced the leniency programme in 2002, and revised it in

\footnotetext{
3 The X-factor is a percentage with which an energy distributer should, during the regulatory period, decrease its allowed revenues from the regulated tariffs for transport.
} 
2007. In 2007, Competition Law in the Netherlands was amended, to allow the fining of individuals for violations of competition law. This implies that individuals also are stimulated to apply for leniency. Because the theory on the impact of a leniency programme on the stability of cartels is inconclusive, the authors argue that the best way to look into answering this stability question is to carry out an empirical impact analysis. They find that the number of cartel discoveries in the Netherlands decreased after the revision of the leniency programme. This could be due to a decrease in the number of cartels that exist, or to a deterioration in cartel detection. By examining several characteristics of all cartel members, Dijkstra and Frisch conclude that enforcement became harsher since the revision, which indicates that more cartels were actually deterred after the revision of the leniency programme. So this study confirms what was indicated in Davies' paper: deterrence has a positive impact on the performance of the economy, but a negative impact on the outcome of possible interventions by the competition authority.

\section{Conclusions}

This Special Issue of De Economist contains a collection of state-of-the-art impact assessment studies. Some studies concentrate on the calculation of the impact of competition policy and regulation on the exchange of welfare between consumers and producers. Others are more concerned with the impact on investments, employment, prices and GDP growth at the macro level or in certain sectors. The importance of such studies should not be underestimated in an era where stimulation of more competition by the general public and politicians is not always deemed to have a positive impact on the economy. The present papers show that maintaining fair competition is important for the prosperity of consumers and for economic development. However, it remains important to keep in mind that questions such as the impact of competition on income distribution and distribution of wealth, and the role authorities can play in looking at fairness are not dealt with in these papers. These essential issues should be at the heart of the research agenda for the next decade.

\section{References}

Broers, B., \& Kemp, R. (2017). Dutch hospital mergers: No evidence for improvement of healthcare quality. In CPI Antitrust Chronicle, July. https://www.competitionpolicyinternational.com/dutch-hospitalmergers-no-evidence-for-improvement-of-healthcare-quality/.

Davies, S. W., \& Ormosi, P. L. (2012). A comparative assessment of methodologies used to evaluate competition policy. Journal of Competition Law and Economics, 8(4), 769-803.

Don, H., Kemp, R., \& Van Sinderen, J. (2008). Measuring the economic effects of competition law enforcement. De Economist, 156(4), 341-348.

European Commission. (2016). The economic impact of enforcement of competition policies on the functioning of EU energy markets-Non-technical summary and technical report. https://doi.org/10.2763/ 55423.

European Commission. (2017). Economic impact of competition policy enforcement on the functioning of telecoms markets in the EU. https://doi.org/10.2763/572780.

Huizingh, E., \& Mulder, M. (2015). Effectiveness of regulatory interventions on firm behavior: A randomized field experiment with e-commerce firms. Small Business Economics, 45(4), 825-840. https://doi. org/10.1007/s11187-015-9666-9. 
Ilzkovitz, F., \& Dierx, A. (2015). Ex-post economic evaluation of competition policy enforcement: A review of the literature. http://ec.europa.eu/competition/publications/reports/expost_evaluation_ competition_policy_en.pdf.

Kemp, R., de Kleijn, H., Lamboo, E., \& Leliefeld, D. I. (2014). Bas Postema en Martijn Wolthoff, 2014. Outcome ACM : Berekeningsmethode van de outcome van ACM en resultaten voor 2013, ACM Working paper 1.

Kemp, R., Kersten, N., \& Severijnen, A. M. (2012). Price effects of Dutch hospital mergers: An ex-post assessment of hip surgery. De Economist, 160(3), 237-255.

Kwoka, J. (2014). Mergers, merger control, and remedies: A retrospective analysis of U.S. Policy. London: MIT Press.

LEAR. (2015). Mergers in the Dutch grocery sector: An ex-post evaluation-Assessing the effects on price and non-price dimensions of competition. https://www.acm.nl/sites/default/files/old_publication/pub licaties/15070_lear-mergers-in-the-dutch-grocery-sector-an-ex-post-evaluation-2015-10-14.pdf.

OECD. (2014). Guide for assessing the impact of competition authorities' activities. http://www.oecd.org/ daf/competition/Guide-competition-impact-assessmentEN.pdf.

OECD. (2016). Reference guide on ex-post evaluation of competition agencies' enforcement decisions. http://www.oecd.org/daf/competition/Ref-guide-expost-evaluation-2016web.pdf.

Van Sinderen, J., \& Kemp, R. G. M. (2008). The economic effect of competition law enforcement: The case of the Netherlands. De Economist, 156(4), 365-385. 